\title{
くも膜下出血治療の現状と今後の治療戦略
}

\author{
石川 達哉
}

\section{Treatment Strategy for Aneurysmal Subarachnoid Hemorrhage (Today and Future)}

Tatsuya IsHIKAwA, M.D.

Department of Surgical Neurology, Research Institute for Brain and Blood Vessels-Akita, Akita, Japan

Summary: Craniotomy and clipping have been the gold standard for treatment of aneurysmal subarachnoid hemorrhage (SAH). From my personal experience, all-over surgical results from craniotomy have not improved, even though surgical skills have improved greatly. Fifteen years has past since endovascular coil embolization became another option. From the result of ISAT, the endovascular coiling appeared to be a robust surgical technique. We are convinced that surgical clipping and endovascular coiling will play a complementary role in the treatment for aneurysm SAH and will improve patients' outcome. Given that younger neurosurgeons experience fewer cases of craniotomy and clipping surgery, a training system is essential to pass on clipping surgery skills.

Each particular patient suffers problems that may worsen their outcome such as preoperative cardiopulmonary problems, delayed vasospasm, and high age.

Careful management suitable to the condition of each patient will be necessary to produce a satisfactory outcome.

\author{
Key words: \\ - subarachnoid hemor- \\ rhage \\ - clipping \\ - embolization \\ - vasospasm
}

Surg Cereb Stroke (Jpn) 36: 259-264, 2008

\section{はじめに}

われわれはくも膜下出血 (以下 SAH と略す)すなわち多 くの場合破裂脳動脈瘤の治療において, すでに 1960 年代 からの歴史を持つ開頭クリッピング術を有しており，顕微 鏡手術を加えて，その有効性は証明されている3）。それに 加えて, 15 年ほど前から，コイル塞栓術が登場してきた3). これは開頭手術では侵襲が大きかったり，アクセス困難な 動脈瘤があるという久点を補完し, さらにいまや日進月歩 の治療技術の進歩により，破裂脳動脈瘤の標準的な治療に

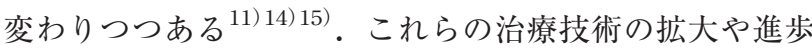
によって, SAHの治療はいかに変貌し, 治療成績はどの
ように改善しているのか，また今後の見通しはどうか，な どについて私見を交えながら概説する。

\section{破裂脳動脈瘤全体の治療成績はどうなっているか}

治療技術の進歩に伴うSAHの治療成績の向上は，個別 の症例からは実感されることもあるが，全体をまとめてみ るとあまり変化がない. 今回は対象として，私が経年的に 治療に一部関与した 3 施設のデータを比較した。これらの 施設ではSAHの治療として開頭クリッピング術が主流で あり，コイル塞栓術はごく一部に限られた。患者の搬送体 制, 重症例の比率, 背景の人口や高齢者の比率など, やや 背景の異なる次の 3 つの施設である. 1. 旭川赤十字病院 
Table 1

\begin{tabular}{lrcc}
\hline & \multicolumn{1}{c}{$\mathrm{n}$} & WFNS I-III & WFNS IV-V \\
\hline Asahikawa (1996-2000) & 315 & $61 \%$ & $39 \%$ \\
Nation wide survey (2003) & 7578 & $68 \%$ & $32 \%$ \\
Sapporo (2004) & 130 & $69 \%$ & $31 \%$ \\
Akita (2005-2006) & 92 & $80 \%$ & $20 \%$ \\
\hline WFNS I-V & \multicolumn{1}{c}{$\mathrm{n}$} & independent & dependent or dead \\
\hline Asahikawa (1996-2000) & 315 & $73 \%$ & $27 \%$ \\
Nation wide survey (2003) & 7578 & $66 \%$ & $34 \%$ \\
Sapporo (2004) & 130 & $82 \%$ & $18 \%$ \\
Akita (2005-2006) & 92 & $68 \%$ & $32 \%$ \\
\hline WFNS 1-III & $\mathrm{n}$ & independent & dependent or dead \\
\hline Asahikawa (1996-2000) & 192 & $92 \%$ & $8 \%$ \\
Nation wide survey (2003) & 5134 & $81 \%$ & $19 \%$ \\
Sapporo (2004) & 90 & $87 \%$ & $13 \%$ \\
Akita (2005-2006) & 74 & $78 \%$ & $22 \%$ \\
\hline
\end{tabular}

(Asahikawa (1996-2000))：1996年 1月〜 2000年 12 月に 開頭クリッピング手術を行った SAH 315 例 (年齢：19-89 (平均 $61.0 \pm 13.1$ ) 歳, 男 106, 女 209), 3 力月後の ADLを GOSにて評価した ${ }^{7)}$. 2. 北海道大学とその関連施設 (Sapporo (2004))：2003年 4 月から 1年間に経験した全 $\mathrm{SAH}$ 症例 154 例 (年齢：23-95 (平均 $62.9 \pm 14.2$ ) 歳, 男 50, 女 104)のうち, 根治治療 (開頭術 121 例, コイル塞栓術 9 例)を行った 130 例において, 3 カ月後の ADLを mRKSに て評価した. 3. 秋田脳血管研究センター (Akita (20052006 ) )：2005年 1 月〜 2006 年 12 月まで全 SAH 106 例 (年 齢 26-91 (平均 60.9 13.8 ) 歳, 男 41, 女 65)のうち, 根治 治療を行った 92 例 (開頭術 87 , コイル塞栓術 5 ) の退院時 の ADLを mRKSにて評価した. なお，いずれの施設でも 脳血管障害を専門としている脳神経外科専門医によって治 療が行われた. 対照として 2003 年に日本脳神経外科学会 によって行われた 369 施設 7578 例の破裂脳動脈瘤に対す る開頭術の成績を用いた (Nation wide survey (2003) $)^{5)}$. またこれらの群において, WFNS grade I-III とIV-Vの 症例の割合, またSAHの全症例とWFNS grade I-IIIの 軽症例における治療後の ADL (評価の時期は異なるが, 自 立，あるいは介助または死亡の割合)を比較し, Table 1 にまとめた．施設間での重症例の比率が異なることなどか ら解釈は難しいが，この 10 年間で着実に進歩がみえると いう結果ではない. Asahikawa と Sapporoのデータは 3 カ月後の ADLの評価をしており, AkitaやNation Wide Surveyに比べ成績は良いが, Akitaではリハビリ転院が 必要な症例では, 本格的リハビリを行う前の退院時に評価 しているために dependentの比率が高くなっている. 評
価時点で dependentでもリハビリ後に independent とな る症例は実際には多い. Nation wide surveyでも退院時

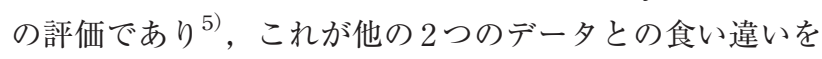
生んでいるのかもしれない. なお ISATの評価は 1 年後の ADLを評価している ${ }^{14)}$.いずれにしてもWFNS grade IIII の軽症の SAH例であれば開頭クリッピング術が主体の 治療でも，一定の時期には約 80\% が independent な状態 になるという結果である.

それではコイル塞栓術を得たことで治療成績は変化した のだろうか. ISATで得られたものは， 1 年後に mRKS 0-2 までの予後となる患者の比率が, コイル塞栓術では $76.3 \%$ であり，開頭クリッピング術の $69.4 \%$ を有意に上回 るという事実であった ${ }^{14)}$ 。その中で ISATに加わった症 例は, WFNS grade I-III にはいる軽症例がほとんどを占 めるので, 軽症例での治療成績が多く反映されているとい う解釈であったＩSATのデータでは対照となった開頭手 術の成績が良くないなどの批判も少なからず存在し, 確か に上に示したわれわれの軽症例の手術成績 (発症 3 力月で はほぼ80\% 以上でindependentになる) と比べても, けっ して良いとはいえない.コイル塞栓術の一番の問題は再出 血と, 再開通による再治療の必要性である.にもかかわら ず最近のISATの追跡調査ではこのコイル塞栓術の ADL にもたらす優位性は，少なくとも 7 年間は続くという結果 である ${ }^{15)}$.またCARATの研究結果ではコイル塞栓術後 の再出血の確率は ISAT の結果ほどは高くはなく, 再治療 を要するものは多くなるという結果である ${ }^{2)}$.

しかしコイル塞栓術を第一に選択している施設では WFNS grade I-IIIではコイル塞栓術と開頭手術をあわせ て $90 \%$ 程度が mRKS 0-2の範囲に回復するという結果も あり ${ }^{23)}$, コイル塞栓術の併用による適切な治療 modality の選択が今後大いに期待されるところである．特に動脈瘤 の部位や大きさ，などその治療に関わる得意・不得意を十 分に検討したうえで，どちらで治療すべきかを決定するべ きで，2つの治療 modality は競合ではなく，補完的な役割 を持つべきだという主張がされている ${ }^{11)}$. 開頭手術の治 療技術は改善していると思われるが, 高齢者の増加と同じ く重症例の増加によって, 全体としてみれば治療成績には 技術の改善が反映されなくなる ${ }^{13)}$. またコイル塞栓術と いう高齢者や重症例に対して特に有利と思われる治療選択 肢が増えたことで, 新たな治療の可能性は増加しつつあ る.しかしコイル塞栓術ではなお，再出血・再治療に関し ては留意すべきである ${ }^{214) 15)}$.コイル塞栓術では破裂脳 動脈瘤を処置しえたかどうかは確信が得られないこと，ま た $10 \%$ 程度で内側から血栓によって止血されている動脈 瘤があり，こういった動脈瘤では血栓の消退に伴い動脈瘤 の再開通は必然的にありうることである ${ }^{8)}$. 常に治療の長 


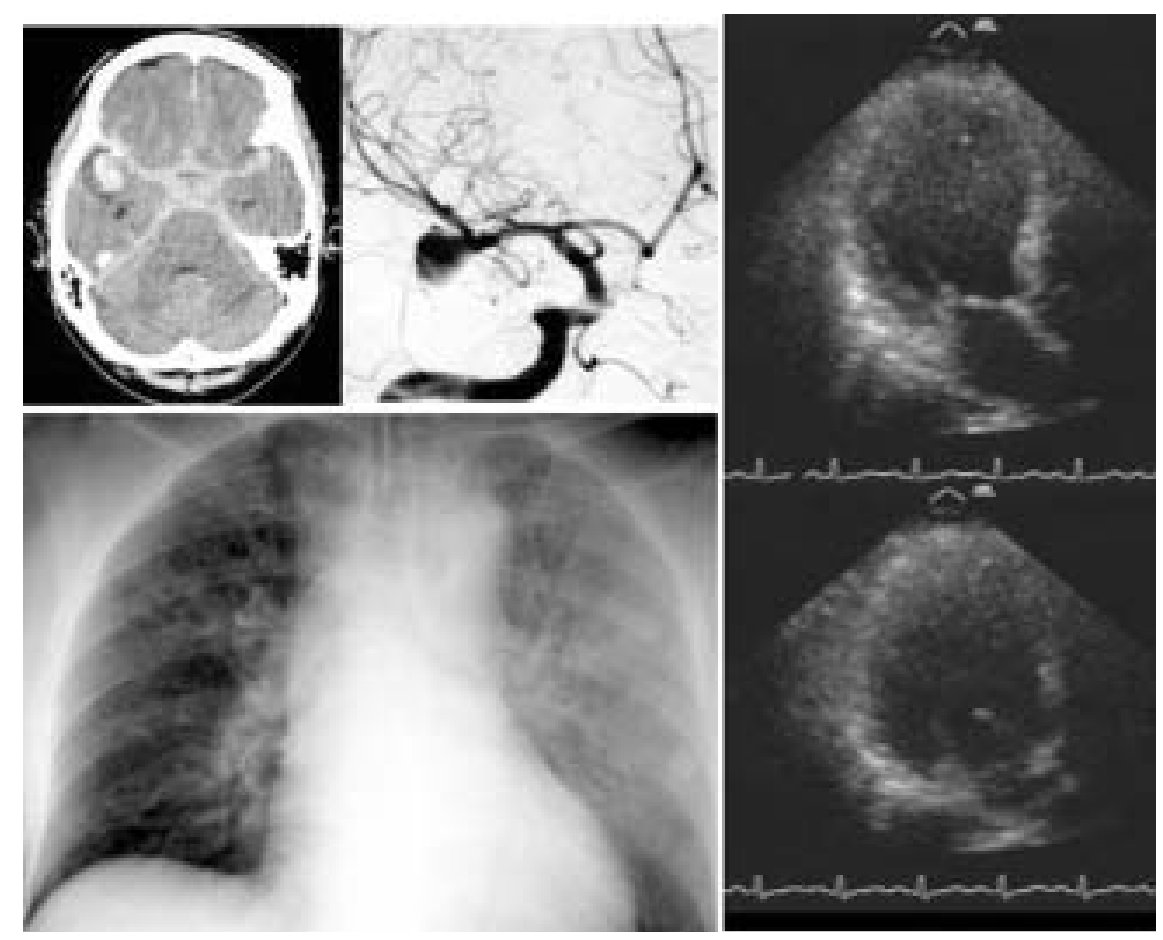

Fig. 1 (Case 1) A 59-year-old woman suffered subarachnoid hemorrhage of WFNS grade $\mathrm{V}$. The CT scan (upper leff) shows diffuse SAH clot with temporal intracerebral hematoma, and the right carotid angiogram (upper middle) shows middle cerebral artery aneurysm. She had neurogenic pulmonary edema by chest X-ray (lower leff) with low saturation (91\%) and low $\mathrm{PaO}_{2}$ : 62 mmHg. Transthoracic Echo cardiograms also demonstrated Takotsubo-cardiomyopathy with ejection fraction at 30\%; When compared ventricular wall movement between diastolic (upper right) and systolic stage (lower right), little contraction can be observed at cardiac apex. Her cardiac function recovered at the next day and she underwent craniotomy and clipping. She fully recovered and returned to previous job.

所・短所を頭に入れ，十分なインフォームドコンセントを 得ながら，個別によく考えながら治療方法を選択していく 必要がある。

開頭手術に確実に残されるものとして, 血腫型の動脈瘤 や大型の動脈瘤, 血栓化動脈瘤など, 難しい条件下での難 しい手術が相対的に増加することだろう。こういった症例 に各術者が少ない経験数から立ち向かわざるを得ないこと を克服するには，後から述べるようにより充実した教育シ ステムを完備するしかないのかもしれない6).

\section{周術期管理の諸問題はどうなっているか}

\section{全身病としてのくも膜下出血の認識}

$\mathrm{SAH}$ 発症時の心電図変化や肺水腫の合併は転帰を悪化 させる要因として注目されていたが, 最近はより全身合併 症に関し注目されるようになってきている. SAHの合併 症としての発熱・貧血・高血糖は有意に死亡率と機能予後 に関連することが知られており，その補正の重要性が指摘 されている ${ }^{21)}$. またタコッボ型心筋症は心尖部心筋の
無・寡動が生じ, 心拍出量が低下し, 肺水腫も合併する病 態である ${ }^{12)}$ 。秋田脳研でもタコッボ型心筋症は 19972006 では 2.7\% (20/740)で, WFNS grade IV・Vの重症 例が 20 例中 14 例と $70 \%$ を占めた。 しかし重症例が多いに もかかわらず mRKS 2 までの良好な転帰となる症例が 13 例 (65\%) と多く, 脳への一次的な損傷よりも, 心拍出量の 低下や合併する肺水腫が重症化の原因となっていると思わ れた。 心機能は 48 時間程度で ejection fraction $50 \%$ 以上 に改善する症例がほとんどであるため，心機能や肺機能の 回復を待って治療を行うことで, 良好な転帰が期待できる。 case 1(Fig. 1)のように, こういった病態が重症例を中心 に隠れていることを考えて治療に臨む必要がある。われわ れは循環器科医師との協力のもと経胸壁の超音波検查は $\mathrm{SAH}$ 患者の初期評価としてルーチンに行うようにしてお り, 有用性が高いと考えている。

\section{症候性脳血管攣縮の現状}

脳血管攣縮の治療成績に関しては，原因の解明や新しい 


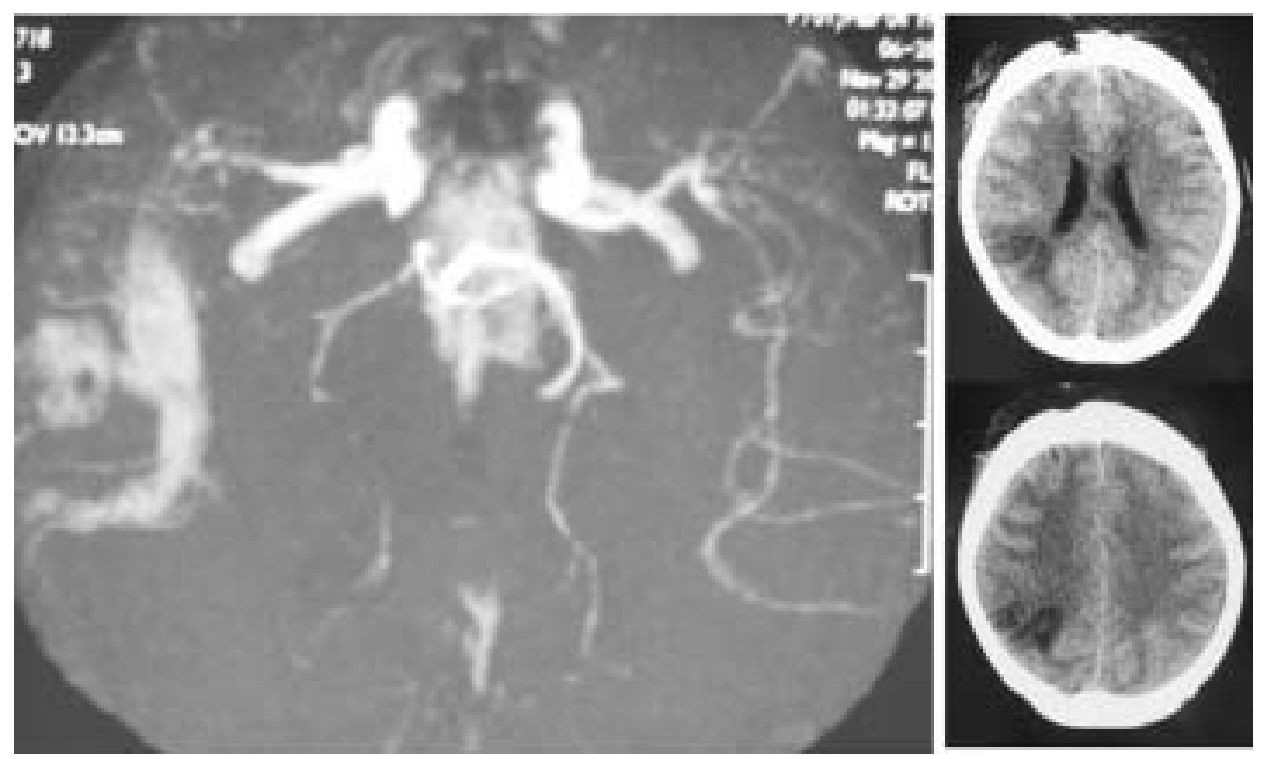

Fig. 2 (Case 2) A 70-year-old woman had subarachnoid hemorrhage of WFNS grade IV due to rupture of anterior communicating artery aneurysm. She experienced deterioration of consciousness and MRA show the stenosis of left middle cerebral artery (left). She received hyperdynamic therapy with the use of dobutamine, and her blood pressure then decrease. Echo cardiogram revealed hypertrophic obstructive cardiomyopathy and use of dubutamine cause and hypotension because of the stenosis from left ventricle. Therefore we gave up the hyperdynamic therapy on her, and consequently she suffered cerebral infarction on the CT scan taken at 10 days after onset of subarachnoid hermorrhage (upper and lower right).

Table 2

\begin{tabular}{lrcc}
\hline & $\mathrm{n}$ & $\begin{array}{c}\text { Symptomatic } \\
\text { vasospasm }\end{array}$ & $\begin{array}{c}\text { Cerebral infarction } \\
\text { due to vasospasm }\end{array}$ \\
\hline Asahikawa (1996-2000) & 302 & $19 \%$ & $11 \%$ \\
Sapporo (2004) & 127 & $28 \%$ & $10 \%$ \\
Akita (2005-2006) & 91 & $29 \%$ & $11 \%$ \\
\hline
\end{tabular}

治療薬・治療手段の開発にもかかわらず，めだって劇的な 改善は得られていない. Kodamaらの irrigationによる脳 血管攣縮の発症率 $2.8 \%$ という目標とすべき数字はある が ${ }^{9)}$, Sen らの報告でも脳血管攣縮により $7 \%$ の患者が死 亡し，他に $7 \%$ が重大な後遺症を生じるとされている ${ }^{20)}$. 開頭手術と異なり生理的なくも膜の状態が保持されること で症候性脳血管攣縮の発生が抑制できることが期待された コイル塞栓術も, Meta-analysisの結果ではその頻度に差 がないというのが現状である ${ }^{19)}$ 。

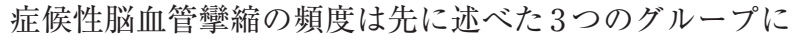
おいて, 症候性脳血管攣縮の発生とそれにより脳梗塞に至 ったかどうかの比率をみると以下の Table 2 のようであ り，成績にここ何年か変わりがなかった。これらの施設で は塩酸ファスジルの使用, ドブタミンの使用, 早期のくも 膜下血腫の排除などは共通しているが，治療・予防の方針
には差異もある。たとえば，Asahikawa・Sapporoでは 積極的に中心静脈カテーテルを入れ，圧を測定しながら， 貧血の補正やコロイド溶液などを積極的に行ってきた。一 方でAkitaでは発熱の原因である中心静脈カテーテルは留 置せず，貧血や低アルブミン血症も脳血管攣縮の治療とし ては積極的には補正せず，早期の経管または経口の栄養摂 取に重点を置いている。なお PTRや塩酸ファスジルの選 択的動注はすべての施設で必要に応じて行われた。これら の治療の差が成績に反映されていないのは，治療の違いが 有利に働いたり，不利に働いたりする患者がそれぞれ一定 の割合で存在するからであろう.

症候性脳血管攣縮の 1 つ側面として，血管攣縮期の心 肺機能の低下があげられる。これに対しドブタミンによる hyperdynamic therapy ${ }^{4)}$ などの治療などがなされてはい るものの, どうしても画一的となり, 細かなパラメー夕に 基づいての循環呼吸管理が併用されていないことも脳血管 攣縮が克服できない 1 つの要因であろう。最近，武藤らは PiCCOによる循環の管理により，正確な循環容量・肺水 分量が測定できることを明らかにし, SAH 後の心機能の 評価に有用で，脳血管攣縮時の管理に有用であることを報 告している ${ }^{17)}$. SAH 後の症候性脳血管攣縮の時期には循 環容量を増やし，心機能を上げることが必要とされ，そう いった治療がなされてきたが，なかには case 2 (Fig. 2)の 
ように hyperdynamic therapyにより，左室流出路の狭窄 が起こったり，かえって心機能が悪化する例も存在する. われわれは循環器科医師との協力のもと，超音波による心 機能の評価を行いながら，患者管理を行っている．各施設 でこういった画一的な治療では解決できない症例が個別に 評価され，きめ細やかな心機能に応じた治療がなされなけ れば症候性脳血管攣縮の治療成績が改善することは期待で きないのかもしれない.

\section{高齢者 SAH の増加}

日本社会は急速な高齢化社会を迎え, 特に秋田県は日本 の平均よりずっと進んだ形で高齢化社会を迎えている. 高 齢者はSAHが重症化することが多く，治療による合併症 も多く，全身合併症をきたしやすく，心機能があがらない ために脳血管攣縮に対する治療がうまくいかず，またいっ たん何か起こると回復する余力もない. case 3 (Fig. 3)の ような高齢者の治療の難しさは世界的にも指摘されている が20), 今後どうしていったらよいかという解決策は, 欧 米から学ぶことは難しく，むしろ秋田県や日本から世界に 発信していく責任があるものである．今後治療適応を含め て十分に議論を行う必要があると思われる.

\section{教育の問題(治療技術習得の問題)}

脳神経外科医はくも膜下出血から多くを学んで成長す る. 救急の対応，全身管理(循環・脳脊髄液), 脳血管撮影, 手術手技，術後管理，そして脳虚血への対応もすべてくも 膜下出血が教えてくれる.

開頭手術症例が減ることは, 確実に経験できる症例を減 じることになるので, 手術治療とその後の管理の技術の後 退につながりかねない．開頭手術に比べコイル塞栓術は learning curve が早く, 熟達するのに必要な症例数は少な いとされるので，コイル塞栓術の術者が多くなる条件は整 っている。しかし，先にも述べたようにこの両者の治療は とってかわられるものではなく，むしろ補完的なものであ る ${ }^{11)}$. 難しい動脈瘤の治療は当分は開頭術に残されるだ ろう。その意味で効率の良い教育方法や，経験の伝え方が きわめて重要である ${ }^{6)}$. 教育の問題は最近では学会でも取 り上げられることが多くなっているし，欧文論文でも動脈 瘤手術への若い研修医の手術への参画は大いに奨励されて いる ${ }^{16) 23)}$ ．しかしすべての脳神経外科医が開頭クリッピ ング術に習熟することは，医療技術が機能分化・高度化し てきたこの時代においては，症例数や機会の問題からもは や不可能になってきており，限定された術者がこの技術を 継承していくべき時代になってしまったのかもしれな ( $^{5)}$.

SAH の特殊性として，特に脳血管攣縮期の管理を通じ

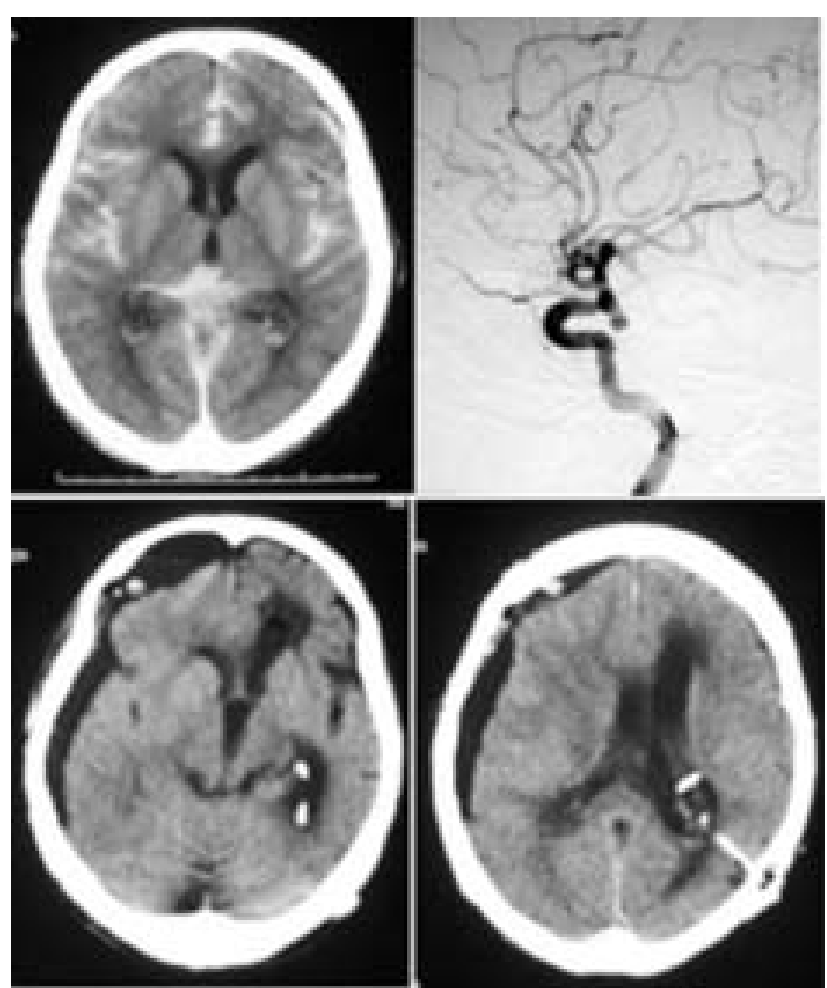

Fig. 3 (Case 3) A 86-year-old woman suffered subarachnoid hemorrhage of WFNS grade II due to ruptured right internal carotid artery aneurysm. CT scan at the admission lupper leffl show diffuse subarachnoid clot at the basal cisterns, and lateral view of the right carotid angiogram (upper right) demonstrated aneurysm at the bifurcation from the posterior communicating artery. She immediately underwent craniotomy and clipping, and recovered from anesthesia. The next day her consciousness was alert, but within a few days she become lethargic because of hyponatremia and subdural hygroma. After these events, she has not been recovered from many problems such as malfunction of ventriculo-peritoneal shunt, where the tip of the ventricle catheter was inserted into the inferior horn of the lateral ventricle as shown in the CT scan taken 1 month after the onset (lower right and leff). She was bed-ridden (mRKS 5) when she was transferred to another hospital at 2 months after the onset.

て，術後管理に対する熱意が非常に患者の予後に関わると いう事情がある。その意味では若い医師が責任感をもって 術後管理を行えるように，初期治療に積極的に参画しても らわなければならない，多少時間を要することや，CTで 低吸収域がでる頻度が高くなっても，予後を低下させるも のでない限りでは, 若い先生に積極的に手術をやってもら うほうがよいのかもしれない。また指導医も指導に熟練 し，指導のやり方を磨く必要があり，相乗的効果を期待し たい。しかし現在の指導医には臨床上の多様な業務に追い やられ，さらにいくら手術や術後管理の教育を一生懸命行 っても，いろいろな要因により自分の業務が楽にならない 
ことから，指導医の熱意が失われてしまっているという不 幸な現状もある。これが若手医師にロールモデルとして描 ける脳神経外科医の像を見失わせ，脳神経外科を志望する 医師の減少へとつながり，その悪循環に拍車をかけている のかもしれない.

脳神経外科医を志望する医師の減少の中で, 前期研修医 にも魅力的に映る脳神経外科医の姿が必要であり，それを 達成するには血管内手術であれ， microsurgeryであれ， $\mathrm{SAH}$ を心となって治療する若手から中堅の湀刺として 働く脳神経外科医がぜひとも必要とされているのである.

\section{さいごに}

本当の意味でのSAHの治療戦略ということであれば, 未破裂脳動脈瘤の治療の適応という難しい問題をはじめと して, また high risk groupのスクリーニング, 生活習慣 病への積極的介入など, 脳神経外科の手だけでは手の届か ないことも多い. また発症後では病院到着前・初療の段階 での再破裂予防, 初期の不整脈・低酸素の改善での早期の 介入など,救急隊への教育や一般人への啓蒙も必要である. $\mathrm{SAH}$ が恐ろしい病気から, 予防できる病気, 治る病気に なることを期待したい.

一緒にSAHに立ち向かってきた秋田県立脳血管研究セ ンター, 旭川赤十字病院脳神経外科, 北海道大学神経外科 ならびに関連施設, 埼玉医科大学総合医療センターの先生 方に哚く感謝いたします。

\section{文献}

1) Banki N, Kopelnik A, Tung P, et al: Prospective analysis of prevalence, distribution, and rate of recovery of left ventricular systolic dysfunction in patients with subarachnoid hemorrhage. $J$ Neurosurg 105: 15-20, 2006

2) The CARAT Investigators: Rates of delayed rebleeding from intracranial aneurysms are low after surgical and endovascular treatment. Stroke 37: 1437-1442, 2006

3) Van Gijn J, Rinkel GJE: Subarachnoid hemorrhage: diagnosis, causes and management. Brain 124: 249-278, 2001

4) Hadeishi H, Mizuno M, Suzuki A, et al: Hyperdynamic therapy for cerebral vasospasm. Neurol Med Chir (Tokyo) 31: 317-323, 1990

5) Hattori N, Kitayama $\mathrm{Y}$, Abe $\mathrm{T}$, et al: Case volume does not correlate with outcome after cerebral aneurysm clipping: A nationwide study in Japan. Neurol Med Chir (Tokyo) 47: 95-101, 2007

6）石川達哉, 数又 研, 中山若樹, ほか: 脳動脈瘤手術の expertを育てる教育はどのようにするか. 脳卒中の外科 35 : 364-369, 2007

7）石川達哉, 上山博康, 数又 研, ほか：破裂脳動脈瘤によ るくも膜下出血に対する開頭直達手術の治療成績. 日救急 医会誌 13: 779-784, 2002

8) Ishikawa $\mathrm{T}$, Nakayama N, Yoshimoto $\mathrm{T}$, et al: How does spontaneous hemostasis occur in ruptured cerebral aneurysms? Preliminary investigation on 247 clipping surgeries. Surg Neurol 66: 269-275, 2006

9) Kodama N, Sasaki T, Kawakami M, et al: Cisternal irrigation therapy with urokinase and ascorbic acid for prevention of vasospasm after aneurysmal subarachnoid hemorrhage. Outcome in 217 patients. Surg Neurol 53: 110-117, 2000

10) Komotar RJ, Ransom ER, Mocco J, et al: Critical postcraniotomy cerebrospinal fluid hypovolemia: risk factors and outcome analysis. Neurosurgery 59: 284-290, 2006

11) Lanzino G, Fraser K, Kanaan Y, et al: Treatment of ruptured intracranial aneurysms since the International Subarachnoid Aneurysm Trial: practice utilizing clip ligation and coil embolization as individual or complementary therapies. J Neurosurg 104(3): 344-349, 2006

12) Lee VH, Connolly HM, Fulgham JR, et al: Tako-tsubo cardiomyopathy in aneurysmal subarachnoid hemorrhage: an underappreciated ventricular dysfunction. $J$ Neurosurg 105: 264-270, 2006

13）松居 徹, 石川達哉：脳血管攣縮治療の最近の動向一これ までの軌跡と今後の展望一. 脳卒中の外科 35: 1-6, 2007

14) Molyneux A, Kerr R, Stratton I, et al: International subarachnoid aneurysm trial (ISAT) of neurosurgical clipping versus endovascular coiling in 2143 patients with ruptured intracranial aneurysms: a randomized trial. Lancet 360: 1267-1274, 2002

15) Molyneux AJ, Kerr RS, Yu LM, et al: International subarachnoid aneurysm trial (ISAT) of neurosurgical clipping versus endovascular coiling in 2143 patients with ruptured intracranial aneurysms: a randomised comparison of effects on survival, dependency, seizures, rebleeding, subgroups, and aneurysm occlusion. Lancet 366: 809-817, 2006

16) Morgan MK, Assaad NN, Davidson AS: How does the participation of a resident surgeon in procedures for small intracranial aneurysms impact patient outcome? $J$ Neurosurg 106: 961-964, 2007

17）武藤達士, 数又 研, 安喰 稔, ほか : くも膜下出血の急 性期ストレスが心機能と血液容量に及ぼす影響一連続心拍 出量測定装置 (PiCCO) を用いた検討一. 脳神経外科 35 : 163-168, 2007

18) Nieuwkamp DJ, Rinkel GJ, Silva R, et al: Subarachnoid hemorrhage in patients $>$ or $=75$ years: clinical course, treatment and outcome. J Neurol Neurosurg Psychiatry 77: 933-937, 2006

19) De Oliveira JG, Beck J, Ulrich C, et al: Comparison between clipping and coiling on the incidence of cerebral vasospasm after aneurysmal subarachnoid hemorrhage: A systemic review and meta-analysis. Neurosurg Rev 30: 22-30, 2007

20) Sen J, Belli A, Albon H, et al: Triple-H therapy in the management of aneurysmal subarachnoid haemorrhage. Lancet Neurol 2: 614-621, 2003

21) Wartenberg KE, Schmidt JM, Claassen J, et al: Impact of medical complication on outcome after subarachnoid hemorrhage. Crit Care Med 34: 617-623, 2006

22) Woodrow SI, Bernstein M, Wallace MC: Safety of intracranial aneurysm surgery performed in a postgraduate training program: implications for training. J Neurosurg 102: 616-621, 2005

23）横山由佳, 牛越 聡, 数又 研, ほか: Coiling かclipping か？：適切な症例分配を目指したチーム医療の模索. 第 6 回日本脳神経血管内治療学会 北海道地方会 抄録集, 2005 